\title{
Climate Change and its Impact on Tourism in Nepal
}

\author{
Anup K.C.*
}

\begin{abstract}
Climate change is a burning issue which had affected different sectors of the environment. It is observed in Nepal in the form of increased frequency of natural disasters, rise in temperature and change in rainfall patterns, shifting of tree line and unfavorable weather change phenomena. It had affected agriculture, hydropower, tourism and livelihood of people in Nepal. Tourism is a travel to a place for the purpose of business, vacation and other activities. It generates enterprise and employment, increases income and helps in sustaining livelihood of local people. There is a close relationship between climate and tourism in ecosystem tourism, coastal tourism, mountain tourism and nature-based tourism. Climate change brings more risks than opportunities by causing regional and seasonal shifts in tourist flows. This paper is based on the review of researches on climate change and tourism. Climate change had caused shift in destination choice of tourists. It had reduced barrier of winter tourism in Nepal in short term. But, unfavorable weather change phenomena had taken lives of many tourists in Nepal and had caused discomfort in transportation in mountain regions. It would decrease the flow of tourists in long term and decrease the income from tourism. It will further cause adverse impact on livelihood of tourism dependent people. To minimize the adverse impact of climate change on tourism, appropriate preventive measures, rescue measures and early warning systems should be implemented in mountain tourism in Nepal.
\end{abstract}

Keywords: Climate change, tourism, methodological issues, Nepal

\section{Introduction}

\subsection{Climate Change}

Climate change is a burning issue throughout the world which had affected different sectors of the environment. It had been observed from historical past and is growing rapidly due to emission of greenhouse gases (K. C., Bhandari, Joshi, \& Aryal, 2013; K.C. \& Ghimire, 2015; K.C., Joshi, \& Aryal, 2014). It is observed mainly

\footnotetext{
Anup K.C. is associated with Central Department of Environmental Science, Tribhuvan University, Kirtipur, Kathmandu, Nepal. Email: kcanup04@gmail.com
} 
in the form of decrease in number of cold days and nights, increase in number of warm days and nights, change in rainfall pattern and change in extreme weather and climate events. Temperature of earth increases by $0.85^{\circ} \mathrm{C}\left(0.65^{\circ} \mathrm{C}\right.$ to $\left.1.06^{\circ} \mathrm{C}\right)$ from 1880 to 2012 but the increase in temperature of the past 15 years $(1998-2012)$ is $0.05^{\circ} \mathrm{C}\left(-0.05^{\circ} \mathrm{C}\right.$ to $\left.0.15^{\circ} \mathrm{C}\right)$ per decade (IPCC, 2014; K.C., 2015). Environmental resources, climatic systems, biodiversity and tourism sectors might be destroyed by $2^{\circ} \mathrm{C}$ rise in earth temperature. It might cause change in rainfall pattern, scarcity of drinking water, melting of glacier, rise of sea level, destruction of forest, tree line shift, decrease in biodiversity and destruction of high altitude ecosystem (Dawson \& Scott, 2013).

\subsection{Climate Change in Nepal}

Climate change had been observed more severely in Hindu Kush Himalayan region including Nepal due to the high altitudinal variation and fragile geographic structures (K. C., et al., 2013; K.C. \& Ghimire, 2015). It had been observed in Nepal in the form of increase in frequency of natural hazards, rise in temperature, change in rainfall patterns, shifting of tree line and unfavorable weather change phenomena (Eugenio-Martin \& Campos-Soria, 2010; K.C. \& Ghimire, 2015). Impacts of climate change is worsen by geographical location, rugged topography, social condition, political influence, lack of skilled manpower, illiteracy and economic prosperity, nature dependent livelihood and poverty (Gurung \& Bhandari, 2009; K. C., et al., 2013). With reference to global Climate Change Vulnerability Index (CCVI), Nepal is fourth most vulnerable country to climate change impacts in the world (CCNN, 2011; MoSTE, 2015).

Temperature of Nepal is rising at the annual rate of $0.04-0.06^{\circ} \mathrm{C}$ per year which is more than global rate (Shivakoti, Lopez-Casero, Kataoka, \& Shrestha, 2015). But the analysis of temperature data from 1975 to 2005 shows increase in average temperature by $0.04^{\circ} \mathrm{C} /$ year. Temperature was increasing across the whole country with higher rate of increase in high altitude and urban areas. Annual rate of increase in temperature of Kathmandu was $0.05^{\circ} \mathrm{C}$ with increasing trend of seasonal and decadal temperature (Baidya, Regmi, \& Shrestha, 2007). The rate of change in temperature was higher in winter season compared to other seasons (Agrawala et al., 2003; Baidya, et al., 2007). Winter season is getting cooler while summer season is getting warmer (EugenioMartin \& Campos-Soria, 2010). Number of warm days and nights has increased while number of cold days and cold nights has decreased (Baidya, et al., 2007; Shivakoti, et al., 2015). Temperature predictions by different models show increase in future temperature by $1.2^{\circ} \mathrm{C}$ till 2050 and $3^{\circ} \mathrm{C}$ till 2100 (Agrawala, et al., 2003). Few models predict rise in temperature of $1.4^{\circ} \mathrm{C}$ by $2030,2.8^{\circ} \mathrm{C}$ by 2060 and $4.7^{\circ} \mathrm{C}$ by 2090 (GWPNepal, 2015; NCVST, 2009). 
Analysis of rainfall data from 1971 to 2005 shows change in annual and seasonal rainfall pattern with overall increase in annual average rainfall by $2.08 \mathrm{~mm}$. There was increase in number of heavy rainfall events and decrease in number of rainy days (Baidya, et al., 2007). Rainfall is in decreasing trend in central and western Terai and increasing trend in western and northern mountains (FAO, 2010). There is prediction of increase in rainfall amount, heavy rainfall events and droughts in the future (GWPNepal, 2014; NCVST, 2009).

\subsection{Impacts of Climate Change}

Climate change had affected agriculture, hydropower, tourism and livelihood of local people in Nepal (Sharma, 2009). These sectors are highly affected by decrease in snow fall and snow cover and change in temperature pattern in mountain region (K.C. \& Thapa Parajuli, 2014a, 2014b). Floods, droughts, landslides and soil erosion have increased due to sudden change in rainfall pattern (FAO, 2010; K. C., et al., 2013). Increase in temperature had caused melting of snow and glacier retreat, modification of hydrology and increase in glacial lake outburst floods (GLOFs) (ADB, 2015; FAO, 2010). It had also altered ecosystem facilities, crop diversity and production cycles (GWPNepal, 2015; MoSTE, 2015). Climate change had adversely affected female, children, disadvantaged people, poor, marginalized and smallholder farmers due to the lack of coping capacity (Shivakoti, et al., 2015). It had resulted in shifting of dominant species of lower region to higher region and disturbing the balance of environment (K.C. \& Ghimire, 2015).

\subsection{Tourism}

Tourism means travelling and staying away from home to a different place for the purpose of business, vacation and other activities. It is a main source of income for sustaining livelihood in most of the developed and developing countries of the world. It has impact on environment, economy, culture, traditions and physical infrastructure. Mountaineering and trekking are major tourism activities in mountain areas that have helped to uplift the livelihood of local people. Tourism generates employment for youths as mountain guides and porters and helps in generating income for their living (K.C. \& Thapa Parajuli, 2014b). It has also created opportunities for enterprise generation through the operation of gift shops, groceries, tea houses and lodges along the trails (Sherpa, 2006).

Tourists throughout the world spend their vacation in mountain areas for trekking and mountaineering, ocean beach for recreational activities and watching diversity of flora and fauna. Tourists travelling in colder climates benefit more from increasing temperature than those travelling to warmer climates (Eugenio-Martin \& Campos-Soria, 2010). They are attracted to the glaciers of mountain region of western North America (D. Scott, Jones, \& Konopek, 2007). Adventurous tourism in Snowy 
Mountain, trekking and mountaineering in higher altitudes, recreational activities near the sea and oceans, religious tours in religious areas and site visit to a naturally and ecologically rich place is the main source of revenue collection for local and national authority (K.C., 2017). About 10\% of Gross Development Products (GDP) was spent in tourism in the world and this revenue has great impact on livelihood of developing economies. It increases income of park management and enhances economy of nearby gateway communities (D. Scott, et al., 2007).

\subsection{Tourism in Nepal}

Nepal has an area of 147,181 sq. km. with diversity of physiography, landscape, climate, topography, ecosystem, cultural heritage and natural resources (K.C., 2016). There are many mountains, protected areas, religions, castes, traditions, religious places and adventurous places (Bhusal, 2007; K.C., 2016). Tourists are attracted to the mountain ranges, cultural heritages, trekking routes and ecotourism sites (K.C., 2016). National as well as international tourists visit the mountain areas of Nepal for trekking and mountaineering. They enjoy indigenous culture, scenic view of different Himalayan ranges and scenic beauty of natural resource. Tourism is helping to increase biological diversity and use of renewable energy, maintaining peace and social security and enhancing income and livelihood of tourism dependent people of mountain region of Nepal (K.C., Rijal, \& Sapkota, 2015).

\subsection{Climate Change and Tourism}

There is a close relationship between climate and tourism in ecosystem tourism, coastal tourism, mountain tourism and nature-based tourism (K.C. \& Thapa Parajuli, 2014a). Climate change increases stress on environmental systems of different locations. It causes sea level rise on small island states, increases the risk of illness in tropical countries and discourages tourism. More frequent periods of extreme heat will cause discomfort in trekking (Viner \& Agnew, 1999). Climate change brings more risks than opportunities by causing regional and seasonal shifts in tourist flows. It adversely affects those climate sensitive countries who are highly dependent on tourism (Ehmer \& Heymann, 2008). Most of the nature-based tourism activities in the Himalayas are weather-sensitive so rain and foggy conditions significantly decrease the quality of the trekking experience in the Himalaya. Tourists can opt for change in destination if weather continues to disappoint them (Rayamajhi, 2012).

Weather and climate affects tourist demand, comfort, satisfaction, tourism industries and natural resources important to the tourism industry. Climate change can influence climate sensitive and economically important tourism sector (Dawson \& Scott, 2013). It had affected tourism in many countries of the world (D. Scott, et al., 2007; Wyss, Abegg, \& Luthe, 2014). It affects specific recreation and tourism activities, demand of tourism and quality of tourism activities (D. Scott, et al., 2007). 
Climate has a great role in destination choice of tourists as sunny day is more favorable than a cloudy or a rainy day (Berrittella, Bigano, Roson, \& Tol, 2006). It can attract more tourists in some place while it can decrease the tourist flow in few places. Few tourists would like to spend their holiday in their own home instead of travelling abroad due to unfavorable weather change phenomena. There will be less impacts of climate change on Zimbabwe as it is the coolest country in the region (Berrittella, et al., 2006).

Climate change affects physical resources and indirectly affects tourism (D. Scott, et al., 2007). It causes phenological change in the ecosystem which in turn affects leaf viewing tourism (Ge, Dai, Liu, Zhong, \& Liu, 2013). It also affects forest fire in mountain regions which in turn affects regeneration rate of plants (D. Scott, et al., 2007). Increase in lake and river temperature affects biological resources of lake and decreases tourist visiting the lake (D. Scott, et al., 2007).

There is a change in temperature by $0.65^{\circ} \mathrm{C}$ while moving every $100 \mathrm{~m}$ elevation in mountain areas which has made tourism more climate sensitive in the area (Dawson \& Scott, 2013). Retreating glaciers due to climate change affects tourism in mountain peaks (D. Scott, et al., 2007). It had more impact on mountain tourism throughout the world (Wyss, et al., 2014). Warmer climate could increase visitors in national parks of mountain region of Canada and United States (D. Scott, et al., 2007).

Visitors of Scandinavian and north-European countries visit other countries during winter months while residents of Mediterranean countries travel to other countries during summer. Tourism demands of any place depend on the socioeconomic characteristics of the household and attractive recreational place of residence (Eugenio-Martin \& Campos-Soria, 2010). Climate change plays a great role in destination selection of tourists. Mediterranean region get more benefits due to cool and rainy season (Bigano, Bosello, Roson, \& Tol, 2008).

Impacts of climate change on tourism are both direct and indirect which are also associated with GHG emissions. Tourism sector advocates inclusion of climate change issues into national policy formulation but could not make significant account of climate change impacts on tourism (Becken \& Clapcott, 2011). To adapt from climate change, ski resorts are built at higher elevations creating skiing atmosphere. Also, investment is done in all-season resorts and non-snow-based tourism activities to adapt from climate change. Recent strategies of snowmaking and advanced adaptation techniques are unable to minimize impact of climate change on tourism in ski areas (Dawson \& Scott, 2013). Climate change had variable impacts at a variable scale which should be addressed through national policy making. Relevant climate change policies should be developed by national governments with appropriate local specifications (Becken \& Clapcott, 2011). 


\section{Methodological Issues of Climate Change and Tourism Researches}

Different researches are conducted by researchers throughout the world to assess the impact of climate change on tourism. They have applied different methodologies to find the relationship between climate change and tourism. This section provides detail review of methodological issues pertaining to the research topic. It would help researchers to identify the appropriate research paper and appropriate methodology for their research.

This paper is based on the review of available research papers and review papers related to climate change and tourism. Different internet sources and published papers were reviewed for preparing this paper. Research conducted in international and national level was reviewed with special focus on national level research of Nepal in this paper.

\subsection{Global Scenario}

With an aim to identify the risk of climate change on health and vulnerable populations of mountainous regions of Hindu Kush Himalaya (HKH) region, Ebi et al (2007) reviewed documents related to consequences of climate change on tourism and health in mountain regions. Research conducted in different parts of the world was reviewed for preparing this paper.

Becken and Clapcott, (2011) conducted a study in Fiji and New Zealand in policy level. They conducted a research to prepare appropriate policy to cope with impact of climate change. Stakeholders of climate change, tourism and both the field were involved for policy making process. The case studies focused on development of strong leadership, commitment and sufficient resource on tourism sector to cope with climate change.

Braun et al. (1999) conducted a pilot study in German Coast at the North and Baltaic Seas to develop a method to measure the sensitivity of destination choice of visitors to changing climatic scenario. Also, psychological experimental approach was applied to assess socio-economic impacts of climate change on tourism.

With the help of scoring model, Ehmer \& Heymann (2008) observed the positive or negative effects of climate change in tourism. Direct climatic effects, substitution effects, regulatory burdens and its substitution effects and adaptation to climatic effects were the four main parameters of the model. To assess differentiations between countries, different weightage was given by dividing the score into different subcategories.

With an objective to assess adaptation practices of tourist resorts to climate change and to assess their potential to reduce climate change by decreasing carbon dioxide emission, Becken (2005) conducted a study in Fiji. The data was collected 
by interviewing stakeholders and experts, tourist operators and accommodation operators. Informal discussion was done with the stakeholders and experts and notes were taken. Background information and results was obtained from interview with industry operator and accommodation survey. Interview with private sector were conducted at the resorts during field visit with the help of semi-structured questionnaire. Operator's attitude towards climate change, adaptation, and mitigation measures was assessed during interview. Information related to energy consumption, climate change and environmental management was assessed through questionnaire survey. The support was taken from Department of Energy and the Ministry of Tourism while questionnaire survey was done with all tourism accommodation providers in Suva, the Coral Coast, the Mamanuca Islands, and Nadi.

Impact of climate change on tourism and sea level was assessed by Bigano et al (2008) by applying Global Vulnerability Analysis. It focuses on the economic assessment of climate change impacts on sea-level rise and changes in tourism flows with the help of Computable General Equilibrium model.

Berrittella et al (2006) studied the impact of climate change in destination choice of tourists. Partial equilibrium analysis was done to assess the distribution of income of tourism in different region. To study the systemic general equilibrium impacts of global warming and climate change, computable general equilibrium model was used. A computable general equilibrium model provides detailed description of an economic system, trade linkages between industries, regions and markets. It simulates and assesses structural adjustments, economic systems, technology, preferences and economic policy. It also simulates impact of exogenous changes in demand patterns and available income in different countries induced by variations in tourism flows.

Empirical analysis and social network analysis technique was used for analysis of interdependence between different factors in mountain tourism region of Alps. To get information from different stakeholders, focus group discussions were carried out. Focus group discussions helped to assess the perception of tourism operators towards impact of climate change in tourism and adaptation measures of tourism towards climate change (Wyss, et al., 2014).

Scott, et al. (2007) conducted a study in Rocky Mountain national parks of western North America to assess the impact of climate change in nature-based tourism. It also assesses the influence of climate change in park tourism of Rocky Mountain region. It focuses on direct and indirect impacts of climate change in visitation to Waterton Lakes National Park (WLNP) (Alberta, Canada). It focuses on empirical assessment of response of visitor towards future climate and its impacts on visitation rate in the Canadian Rocky Mountains. For this, statistical model of monthly visitation and 
climate was prepared to examine the direct impact of climate change on visitation rate of tourists. To test the regression-based climate-visitation models, a multi-year data set of monthly observed visitation were used to assess the impact of climate change on the timing and number of annual visitors to WLNP. Visitor survey was also used to explore the impact of climate change to WLNP's natural landscape and future visitation.

Eugenio-Martin and Campos-Soria (2010) assess the impact of climate on choice of holiday destination of tourists and tourism demand of a place. They use bivariate probit model which uses new regional climate index based on a double-hurdle model of temperature and rainfall. The methodology utilizes number of months of a year having good climate for tourism purposes. Information about socioeconomic characteristics of European households, region of residence and climate was taken for the analysis. For collecting socioeconomic information, household survey was conducted with the help of stratified weighted survey of 16183 households in 1997. Information from Austria, Belgium, Denmark, Finland, France, Germany, Greece, Ireland, Italy, Luxemburg, Netherland, Portugal, Spain, Sweden, and the United Kingdom was taken from household survey. They use GIS and nonparametric techniques for estimating probabilities related to climate and tourism.

Dawson and Scott (2013) examined the combined regional impacts of climate change on tourism in US Northeast region by modeling local-level impacts at all 103-ski areas. Vulnerabilities caused by variable climate change in ski tourism were assessed. To calibrate the change in temperature of higher elevation of ski area, available snowmaking technologies and generic lapse rates were used. Future climate change scenarios and the baseline period were derived from gridded climate data of Northeast Climate Impact Assessment. Six climate change scenarios and three different Global Climate Models were used in the study. Average results of three Global Climate Models were used for lower and higher emission scenarios of three future time periods.

\subsection{National Scenario}

Nepal and Nepal, (2004) conducted a study on Sagarmatha (Mt. Everest) National Park, Nepal to assess the impact of visitors on different environmental components of trail. For this study, 90 kilometers distance of 7 trails and 208 trail segments was taken for analysis. To assess the status of trail, four-class rating system was used. Spatial analysis of impacts was done with the help of Arc/Info and Arc/View geographic information system (GIS). Ecological impacts were well established on camp sites and trails with the help of standard qualitative techniques replicable in different ecological settings. Trail survey manual was prepared with the help of qualitative and quantitative data and data analysis techniques. 
Rayamajhi (2012) studied the impact of climate change and tourism in Annapurna Conservation Area of Nepal. The study was conducted with the help of perception analysis of the stakeholders in the tourism sector. Mainly the lodge-owners, guides and tourists in the Annapurna Trekking Trail were interviewed and their perception related to climate change and tourism was assessed.

To assess the impact of climate change on tourism, K.C. \& Thapa Parajuli (2014a) conducted a study in Manaslu Conservation Area of Gorkha District in central Nepal. The field study was conducted in the month of April and May in 2012 in hilly and mountain region of Nepal. The study was done with the help of 5 KIIs, 3 FGDs and 76 questionnaire surveys with local people and secondary data of climate and tourism. Clustered random sampling was done with the help of semi-structured questionnaire in Nepali language. Relationship between climate change and tourism was studied with the help of graphical and correlation analysis.

\subsection{Climate Change and Its Impact on Tourism in Global Scenario}

Climate change could affect selection of destination for vacations which may have either positive or negative impacts. In North German coastal region, climate change had negative impact as a choice of vacation destination of tourist. International visitors are less willing to travel there so local and regional tourism stakeholders should apply appropriate steps to reduce the adverse impacts (Braun, et al., 1999).

Climate change had increased stresses on environmental systems of different tourist destinations. Rise in sea level had adverse impacts on popular tourist destination of small island states such as Maldives. Increasing risk of illness in different tourist destinations is discouraging tourism. Increase in temperature causes discomfort in resorts of the Eastern Mediterranean. Decrease in cloud cover in Australia will increase exposure to the sun's harmful rays. Emergence of malaria in Spain will affect tourism in long run. Less snowfall may cause shorter skiing seasons in winter season in Alps. Sunshine, heat and warmer climate will enhance benefit of holiday destinations in UK by attracting international, national and local visitors (Viner \& Agnew, 1999).

Up to 2030, there would be negative effects of higher temperatures in the Mediterranean region, France, Italy and Austria but there will be positive impacts in Switzerland. Climate change causes more problems and burden to the poorer countries who are taking tourism as a main driver of development. Also, Canada, New Zealand and USA will be benefited from climate change (Ehmer \& Heymann, 2008).

Moore (2011) had assessed the impacts of climate change on tourism from economic perspectives in Barbados. Climate change policies may reduce tourism mobility in few areas of the country. Recent policies of United Kingdom has increased price of flights to Barbados which may affect tourism in Barbados. 
Simpson et al. (2011) observed that Caribbean destinations may be too hot for tourists during some seasons. During summer, there will be intolerable heat in few locations. Increase in temperature will cause competition of tourism in Mediterranean and Caribbean region. Climate change increases operation costs of tourism operators in insurance, heating costs, cooling costs, pest management and water supply for drinking and irrigation. Annual losses from wind, storm surge, and inland flooding have increased. Rise in sea level of 1 meter will increase the risk of inundation in 266 out of 906 tourism resorts and 26 out of 73 airports in Caribbean region.

Scott (2012) observed that climate change shifts travel patterns, increases tourism cost in temperate regions and decreases tourism costs in warmer region. Climate change had also shifted tourism from Northern part of Europe to Mediterranean and the Caribbean, North America to the Caribbean. Increase in income from tourism and reduction of carbon footprint is occurring due to increase in length of stay.

Fall foliage season is an important time for sightseeing activity in the world. Climate change had caused delay of timing of fall foliage vacation season. Increase in $1^{\circ} \mathrm{C}$ will cause delayed beginning by 5.3 days, delayed best date by 3.5 days and the end of fall foliage vacation by 3.7 days. Start of fall foliage season was delayed in 1990s, best date of fall foliage vacation was delayed in early 2000s and 1990s and end of fall foliage vacation season was delayed in early 2000s. It has adversely affected tourists and the tourism industry by changing the timing of vacation trips and their promotion (Ge, et al., 2013).

There is need of information about impact of climate change on tourism. It is necessary to include climate change in tertiary education syllabus of different subjects such as tourism, resource management engineering and architecture. Mapping of all tourism infrastructure and health hazards of different locations need to be carried out for implementing nation-wide risk management strategy for tourism and climate change (Becken, 2005).

Warmer countries will have more disadvantages while countries of higher latitudes have more advantages in tourism from climate change. Rise of sea level will increase loss of land by $0.839 \%$ in South East Asia, $0.396 \%$ in South Asia and $0.167 \%$ in rest of the World. Rise in sea level by $25 \mathrm{~cm}$ till 2050 will cause loss of GDP by $0.1 \%$ in South East Asia, $0.0004 \%$ in Canada and gain in GDP of Australia, New Zealand, Western Europe, Middle East and South Asia (Bigano, et al., 2008).

Ebi et al (2007) observed that the main climate-related risks in the Hindu Kush Himalayan region were expansion of vector-borne diseases, expansion of diarrheal diseases and increase in rainfall events leading to floods, landslides, death and injuries. Glacial lake outburst flood may cause substantial destruction and loss of life while rapid snowmelt reduce freshwater in upland regions and downstream countries. 
There are milder winters and longer growing seasons of crops and vegetation in mountain regions which may lead to adverse impact on public health of local people in the area.

The study concluded that tourism agencies need to enhance their skill and capacity to address climate change. Also, climate change and tourism sector requires a strong policy framework led by a government agency to convert private ownership into public ownership and global flow of resource into local flow of resource (Becken \& Clapcott, 2011).

Tourism is a resilient sector as there is capacity to attract new ideas and avoid the traditional practices. Effect of climate change on tourism was felt differently by different people. Participants of focus group discussion were not sure about the winners and losers from climate change. Climate change enhances product innovation and tourism rearrangements in tourism sector. Rapid melting of glacier and permafrost in alpine region will have negative impact on tourism sector associated with climate change phenomena. Local tourism stakeholders had a great role in implementing climate change adaptation measures for adapting toward adverse changing scenario (Wyss, et al., 2014).

Impact of climate change on global economy is negligible in 2010 while climate change may alters GDP by $-0.3 \%$ to $+0.5 \%$ till 2050 and may lead to negligible global loss. The main losers will be Western Europe, energy exporting countries, Caribbean and The Mediterranean. Caribbean will be too hot and less pleasant for tourist. Tropical nations will be less popular due to global warming and unpleasant weather. Energy exporting countries will lose a lot due to fall in energy demand. There will be positive impact of climate change in tourism in Eastern Europe, North America, Japan, Australasia and Russia while there will be neutral effects on China and India (Berrittella, et al., 2006).

Scott et al (2007) projected that there will be increase in annual visitation between 6 percent to 10 percent in the 2020s and it will increase by 10 percent to 36 percent in the 2050s. Environmental change scenarios shows minimal impact on visitation rate of tourists from 2020s to 2050s but there will be negative impact on visitation rate of tourist for the 2080s scenarios by increase in temperature. More than 19\% respondents would not visit the park and $37 \%$ would less often visit the park due to increase in temperature. Climate-visitation model shows that all the climate change scenarios would increase annual visitation to Waterton Lakes National Park (WLNP) (Alberta, Canada).

About $76 \%$ of the Danish people, $72.52 \%$ of Dutch people, $70.13 \%$ of Swedish people, $67.09 \%$ of Finnish people and $34.66 \%$ of Portuguese people visit other places in a year. It may be due to the financial status of these citizens. The frequency of travel of Finnish citizen is most (1.34) while that of Portugese citizen is the least (0.40). 
Finnish citizen visit three times more than Portuguese in any year due to difference in gross domestic product, financial constraints, labour condition and family matter. If the community of residence is large, people will visit to any destination. Coastal people like domestic visit than visit to abroad. Construction of national airport has a positive impact on domestic tourism and negative impact on international tourism while construction of international airports has a negative impact on domestic tourism and a positive impact on international tourism. High rate of hotel prices in the place of residence does not affect domestic visit but increases international visit. The climate index has great role in tourism as better climate in the place of residence increases domestic visit and decreases international visit. Visit of people to a new place will change in relation to climate. Zero climate index causes $18 \%$ chances of domestic visit and $45 \%$ chances of international visit. Climate index value of 3 indicates $25 \%$ chances in both types of visit (domestic and international). Climate of a place is a strong indicator for selecting holiday destination of people. They showed that residents in regions with better climate indices have a higher probability of travelling domestically and a lower probability of travelling abroad (Eugenio-Martin \& Campos-Soria, 2010).

Climate change had increased risk of individual ski operations in climatically and geographically disadvantaged regions. Ski tourism resorts at higher elevation having access to large urban markets are least affected by climate change. Climate change will cause historic contraction and consolidation of ski industry. But those industries which can adapt from climate change and which can develop new technologies would get benefit from stable tourism revenue. Climate change is the main factor which can affect ski industry (Dawson \& Scott, 2013).

\subsection{Climate Change and Its Impact on Tourism in National Scenario}

Different studies related to climate change and tourism is carried in different region of Nepal. Most of these studies are focused in mountain areas of Nepal where trekking and mountaineering is the main occupation and main source of income of the local people. The tourism in this area is climate sensitive so climate change had impact on tourism in this region of Nepal.

In Lower Mustang of Nepal, people perceived warm and dry winter, decrease in water availability and draught as a result of climate change. It has promoted tourism by reducing barrier for trekking tourism in winter season but has increased the loss of natural scenic beauty of the place. Natural scenic beauty of mountains was reduced due to less snowfall in winter with thin cover of snow. Hotel owners were affected badly due to water scarcity in Muktinath, Kagbeni, Puthang, Marpha and Lete. Decrease in sources of drinking water in the existing spring had increased burden of bringing water from the new source (Lama, 2010). 
Subedi \& Chapagain (2011) observed decrease in number of tourists from 2002 to 2006 in Manang valley of Nepal. Tourists in Annapurna, Everest and Langtang region has decreased drastically from about 100,000 in 2001 to 67,000 in 2006 . It might be due to political instability, climate change impacts and other reasons in the country. After 2007, the number of trekkers in Upper Manang had increased and reached more than 14,192 in 2007.

Rayamajhi (2012) observed that $69 \%$ of the tourism stakeholders perceived changes in the tourism season but $49 \%$ perceived impact of climate change in their work. About $63 \%$ tourist had increased in the region despite the change in climate and shift in tourism seasons. About 83\% lodge owners and guides believed that climate change would have an impact on tourism. Rise in temperature had not caused any discomfort to the tourist but instable rainfall pattern had caused discomfort to the tourists. Increased intensity of rainfall, landslides, floods and other natural disasters may affect flow of tourist in the future.

In Manaslu Conservation Area of Gorkha, there was increase in annual maximum temperature and mean temperature by 0.10 and $0.02^{\circ} \mathrm{C} /$ year, decrease in annual minimum temperature by $0.06^{\circ} \mathrm{C} /$ year and increase in average annual rainfall by $3.19 \mathrm{~mm} /$ year. About $93 \%$ people have perceived change in climate, $36 \%$ people perceived the most significant impact of climate change on rainfall and water supply and $82 \%$ people perceived unfavorable weather change. People had perceived rise in temperature, rapid melting of snow, increase in rainfall amount in lower belt, decrease in snowfall in higher belt and unfavorable weather change phenomena. From the people perception, $96.10 \%$ respondents felt that number of tourist was increasing in Manaslu Conservation Area. People felt the increasing trend as a result of climate change and tourism promotional activities. In the long term, climate changes will have more severe adverse impact on tourism affecting their livelihood. All the key informants felt that the climate change had positive significant impact on tourism currently but in long run, increase in temperature, change in rainfall pattern and water availability and unfavorable weather change might cause adverse impact on tourism in the future. (K.C. \& Thapa Parajuli, 2014a).

Due to the unfavorable climate change phenomena, there is impact on trekking and mountaineering tourism in Nepal. Untimely and high intense rainfall and snowfall had caused serious threat to the mountaineers, trekkers and travelers. It is difficult to complete the visit in a target time for the tourist as that happened in November 2010 in Mt. Everest (Sagarmatha) region of eastern Nepal. Bad weather had stopped flights for several days and caused economic and other social problems to the tourists. More than 1000 tourists were stranded in Lukla region (altitude of $2500 \mathrm{~m}$ above sea level) due to the cancellation of flight by thick fog generation and wind. Few tourists had chosen alternative route of trekking to Jiri 
from Lukla region while many tourists had waited for several days for aircraft (Sangraula, 2010).

In October 2014, more than 32 people were killed by sudden snowstorm in Annapurna Conservation Area of western Nepal. Hundreds of trekkers were trapped at more than $5000 \mathrm{~m}$ altitude from sea level in Thorong La Pass area. Tourists were rescued with the help of helicopters and soldiers in the area. Many tourists were trapped by similar weather change phenomena in Manaslu Conservation Area in same time as reported by the authorities. Appropriate early warning system in the region would minimize the impact of disaster in the region (Burke \& Walker, 2014).

In April 2015, devastating earthquake in Nepal had caused snow avalanches in Mt. Everest region at about $7000 \mathrm{~m}$ altitude from mean sea level. More than 17 people had died and 61 were injured. More than 100 mountaineers were safe in Camp 1 and 2. It was the second incidence in 2 years period as 16 Sherpas were killed in an avalanches and icefall last year (2014) in Mt. Everest region (Beaumont, 2015). At the same time in 2015, devastating earthquake causes avalanches in Langtang region. It buried 116 houses, killed 308 people (176 local residents, 80 foreigners, and 10 army personnels) (Callaghan \& Thapa, 2015).

Climate change had reduced the barrier of snow in winter season and had increased the number of tourists in short term. In the long term, it will have adverse impacts on tourism. Increase in temperature will cause rapid melting of snow and ice in the mountains and destruction of flora and fauna. It will decrease natural scenic beauty of hills and mountains of Nepal. Visitors will select alternative tourism location and better destination for trekking and mountaineering. Tourists will be demotivated to travel due to the adverse climate change phenomena in Nepal. Also impact on tourism industry might affect the livelihood pattern of the local people who depend on tourism for survival. It is necessary to apply mitigation and adaptation strategies to combat climate change. To decrease the death of tourists from unfavorable weather phenomena, early warning system should be installed in trekking and mountaineering route of Nepal. Apart from these, rescue Centre for tourists should be established in different trekking routes of Nepal. To solve the problem of delayed flight due to bad weather, alternative route of trekking should be enhanced.

\section{Conclusions}

Climate has a great role in influencing tourism demand and destination choice of holidays of tourists. Tropical countries will have unpleasant weather for tourists than temperate areas from increasing temperature scenario. Tourist will change their holiday destination from unpleasant weather to fine weather location. The developing and developed countries which depend on tourism as a major source of income will be affected from the changing climatic scenario. Trekking and mountaineering 
tourism of Nepal is highly climate sensitive tourism. Unfavorable weather change phenomena had caused unpleasant situation for the trekkers and mountaineers. Sudden climatic disasters had taken lives of many tourists in the past. In the short term, barrier of snow in winter is reduced due to increase in temperature. In the long term, climate change will have adverse impact on tourism. Less snow in mountains and less greenery in the hills will decrease the scenic beauty of trekking routes. It will not attract tourist in the future as tourist will choose other better alternative place for spending holidays. The people who are highly dependent on tourism for income generation will be affected badly. It will cause adverse impact on livelihood of local people of trekking and mountaineering route. There is need of advanced early warning system, adequate rescue measures and alternative tourism route for minimizing the impact of climate change on tourism in Nepal.

\section{References}

ADB. (2015). The Asian Development Bank And The Climate Investment Funds Country Fact Sheets. Manila, Philippines: ADB Climate Change and Disaster Risk Management Division.

Agrawala, S., Raksakulthai, V., Aalst, M. V., Larsen, P., Smith, J., \& Reynolds, J. (2003). Development and Climate Change in Nepal: Focus on Water Resources and Hydropower. Paris, France: Organisation for Economic Co-operation and Development.

Baidya, S. K., Regmi, R. K., \& Shrestha, M. L. (2007). Climate Profile and Observed Climate Change and Climate Variability in Nepal. Kathmandu, Nepal: Department of Hydrology and Meteorology.

Beaumont, P. (2015, April 26, 2015). Deadly Everest Avalanche Triggered by Nepal Earthquake, The Guardian. Retrieved from https:/www.theguardian.com/ world/2015/apr/25/deadly-everest-avalanche-triggered-by-nepal-earthquake

Becken, S. (2005). Harmonising Climate Change Adaptation and Mitigation: The Case of Tourist Resorts in Fiji. Global Environmental Change, 15(4), 381-393. doi: 10.1016/j.gloenvcha.2005.08.001

Becken, S., \& Clapcott, R. (2011). National Tourism Policy for Climate Change. Journal of Policy Research in Tourism, Leisure and Events, 3(1), 1-17. doi: 10.1080/19407963.2011.539378

Berrittella, M., Bigano, A., Roson, R., \& Tol, R. S. J. (2006). A General Equilibrium Analysis of Climate Change Impacts on Tourism. Tourism Management, 27, 913924. doi: 10.1016/j.tourman.2005.05.002

Bhusal, N. P. (2007). Chitwan National Park: A Prime Destination of Eco-Tourism in Central Tarai Region, Nepal. The Third Pole, 5(7), 70-75. 
Bigano, A., Bosello, F., Roson, R., \& Tol, R. S. J. (2008). Economy-wide Impacts of Climate Change: A Joint Analysis for Sea Level Rise and Tourism. Mitigation and Adaptation Strategies for Global Change, 13(8), 765-791.

Braun, O. L., Lohmann, M., Maksimovic, O., Meyer, M., Merkovic, A., Messerschmidt, E., ... Turner, M. (1999). Potential Impact of Climate Change Effects on Preferences for Tourism Destinations. A Psychological Pilot Study. Climate Research, 11, 8.

Burke, J., \& Walker, P. (2014, 17 October 2014). Nepal Blames Cheap Tourists for Falling Victim to Snowstorm in Himalayas, The Guardian. Retrieved from https:// www.theguardian.com/world/2014/oct/17/nepal-cheap-tourists-snow-disaster

Callaghan, A., \& Thapa, R. (2015, September 28, 2015). An Oral History of Langtang, The Valley Destroyed by Nepal Earthquake Retrieved February 10, 2017, from https://www.outsideonline.com/2016856/oral-history-langtang-valleydestroyed-nepal-earthquake

CCNN. (2011). Governance of Climate Change Adaptation Finance in Nepal. Kathmandu, Nepal: Climate Change Network Nepal.

Dawson, J., \& Scott, D. (2013). Managing for Climate Change in the Alpine Ski Sector. Tourism Management, 35, 244-254. doi: 10.1016/j.tourman.2012.07.009

Ebi, K. L., Woodruff, R., Hildebrand, A. V., \& Corvalan, C. (2007). Climate Changerelated Health Impacts in the Hindu Kush-Himalayas. Eco Health, 4, 264-270. doi: 10.1007/s10393-007-0119-Z

Ehmer, P., \& Heymann, E. (2008). Climate Change and Tourism, Where Will the Journey Lead? In T. Just (Ed.). Frankfurt, Germany: Deutsche Bank AG, DB Research.

Eugenio-Martin, J. L., \& Campos-Soria, J. A. (2010). Climate in the Region of Origin and Destination Choice in Outbound Tourism Demand. Tourism Management, 31, 744-753. doi: 10.1016/j.tourman.2009.07.015

FAO. (2010). Implications of Climate Change for Agriculture and Food Security and Adaptation Priorities in Nepal Rome, Italy: Food and Agriculture Organization of the United Nations.

Ge, Q., Dai, J., Liu, J., Zhong, S., \& Liu, H. (2013). The effect of climate change on the fall foliage vacation in China. Tourism Management, 38, 80-84. doi: 10.1016/j. tourman.2013.02.020

Gurung, G. B., \& Bhandari, D. (2009). Integrated Approach to Climate Change Adaptation. Journal of Forest and Livelihood 8(1), 90-99.

GWPNepal. (2014). Climate Vulnerability and Gap Assessment Report on Flood and Drought (Lower Rapti River Basin Case Study) Kathmandu, Nepal: GWP Nepal/ Jalsrot Vikas Sanstha (JVS). 
GWPNepal. (2015). Stocktaking: Climate Vulnerability on Agricultural Sector for National Adaptation Plan Process. Kathmandu, Nepal: Jalsrot Vikas Sanstha (JVS)/GWP Nepal.

IPCC. (2014). Climate Change 2014 Synthesis Report Summary for Policymakers IPCC's Fifth Assessment Report (AR5) Geneva Intergovernmental Panel on Climate Change.

K. C., A., Bhandari, G., Joshi, G. R., \& Aryal, S. (2013). Climate Change Mitigation Potential from Carbon Sequestration of Community Forest in Mid Hill Region of Nepal International Journal of Environmental Protection, 3(7), 33-40.

K.C., A. (2015). Climate Change and its impact on hydropower development in Nepal. Vidhyut, 26(1), 25-29.

K.C., A. (2016). Hydropower Development, Ecotourism and Green Economy in the Context of Nepal. Vidhyut, 26(2), 9-13.

K.C., A. (2017). Ecotourism in Nepal. The Gaze: Journal of Tourism and Hospitality, $8(1), 1-19$.

K.C., A., \& Ghimire, A. (2015). High-Altitude Plants in Era of Climate Change: A Case of Nepal Himalayas. In M. Ozturk, K. R. Hakeem, I. Faridah-Hanum \& R. Efe (Eds.), Climate Change Impacts on High-Altitude Ecosystems (Vol. 1, pp. 177189). Switzerland: Springer International Publishing.

K.C., A., Joshi, G. R., \& Aryal, S. (2014). Opportunity Cost, Willingness to Pay and Cost Benefit Analysis of a Community Forest of Nepal. International Journal of Environment, 3(2), 108-124.

K.C., A., Rijal, K., \& Sapkota, R. P. (2015). Role of ecotourism in environmental conservation and socioeconomic development in Annapurna conservation area, Nepal. International Journal of Sustainable Development \& World Ecology, 22(3), 251-258. doi: 10.1080/13504509.2015.1005721

K.C., A., \& Thapa Parajuli, R. B. (2014a). Climate Change and Its Impact on Tourism in the Manaslu Conservation Area, Nepal. Tourism Planning \& Development, 13. doi: 10.1080/21568316.2014.933122

K.C., A., \& Thapa Parajuli, R. B. (2014b). Tourism and Its Impact on Livelihood in Manaslu Conservation Area, Nepal. Environment Development and Sustainability, 16, 1053-1063. doi: 10.1007/s10668-013-9512-7

Lama, A. K. (2010). Vulnerability of Nature Based Tourism to Climate Change: Stakeholders' Perceptions of and Response to Climate Change in the lower Mustang Region of the Annapurna Conservation Area. Master of Parks, Recreation and TourismManagement Lincoln University, Christchurch, New Zealand. 
Moore, D. W. (2011). An Economic Assessment of the Impacts of Climate Change on Tourism in Barbados (Vol. 14). Trinidad: University of Oxford.

MoSTE. (2015). Indigenous and Local Climate Change Adaptation Practices in Nepal. Kathmandu: Ministry of Science Technology and Environment, Government of Nepal.

NCVST. (2009). Vulnerability Through the Eyes of Vulnerable: Climate Change Induced Uncertainties and Nepal's Development Predicaments: Institute for Social and Environmental Transition-Nepal (ISET-N, Kathmandu) and Institute for Social and Environmental Transition (ISET, Boulder, Colorado).

Nepal, S. K., \& Nepal, S. A. (2004). Visitor Impacts on Trails in the Sagarmatha (Mt. Everest) National Park, Nepal. Ambio: A Journal of the Human Environment, 33(6), 334-340.

Page, S. J. (2009). Current Issue in Tourism: The Evolution of Travel Medicine Research: A New Research Agenda for Tourism? Tourism Management, 149-157, 149-157.

Rayamajhi, S. (2012). Linkage between Tourism and Climate Change: A Study of the Perceptions of Stakeholders along the Annapurna Trekking Trail. Nepal Tourism and Development Review 2(1), 60-86.

Sangraula, B. (2010, November 20, 2010). 1,000 Tourists Stranded in Lukla Due to Week-Long Flight Shutdown, Republica.

Scott, D., Jones, B., \& Konopek, J. (2007). Implications of Climate and Environmental Change for Nature-based Tourism in the Canadian Rocky Mountains: A case study of Waterton Lakes National Park. Tourism Management, 28, 570-579. doi: 10.1016/j.tourman.2006.04.020

Scott, M. M. (2012). Climate Change and Sustaining Caribbean Tourism: UNWTO, UNEP.

Sharma, K. P. (2009). Climate Change Trends and Impacts on Livelihood of People. Kathmandu, Nepal: Jalsrot Vikas Sanstha/Nepal Water Partnership.

Sherpa, Y. (2006). Mountain Tourism: A Boon or a Bane? Impacts of Tourism on Himalayan Women. Kathmandu, Nepal: Federation of Women Entrepreneurs association Of Nepal.

Shivakoti, B. R., Lopez-Casero, F., Kataoka, Y., \& Shrestha, S. (2015). Climate change, changing rainfall and increasing water scarcity: An integrated approach for planning adaptation and building resilience of smallholder subsistence livelihoods in Nepal IGES Research Report 2014-07. Hayama, Japan: Institute for Global Environmental Strategies (IGES). 
Simpson, M., Scott, D., \& Trotz, U. (2011). Climate Change's Impact on the Caribbean's Ability to Sustain Tourism, Natural Assets, and Livelihoods: Inter-American Development Bank.

Subedi, B. P., \& Chapagain, P. S. (2011). Tourism Development in Upper Manang Valley of Annapurna Region. Nepal Tourism \& Development Review 1(1).

Sung, T. P., Bagul, H. B. P., Sentian, J., \& Dambul, R. (2012). Developing and Promoting a Highland Community Livelihood for Sustainable Tourism: The Case of Kg. Bundutuhan, Ranau, Sabah. Malaysia Journal of Society and Space, 8(5), 94 - 99.

Viner, D., \& Agnew, M. (1999). Climate Change and Its Impact on Tourism. Norwich UK. NR47T: Climate Research Unit (CRU), University of East Anglia.

Wyss, R., Abegg, B., \& Luthe, T. (2014). Perception of Climate Change in Tourism Governance Context. Tourism Management Perspectives, 11, 69-76. 